\title{
Skin Adverse Reactions to Novel Messenger RNA Coronavirus Vaccination: A Case Series
}

\author{
Maria Francesca Peigottu ${ }^{1}$, Caterina Ferreli ${ }^{2} \mathbb{D}$, Maria Giovanna Atzori ${ }^{1}$ and Laura Atzori ${ }^{2, *}$ (D) \\ 1 Dermatology Unit, San Francesco Hospital, 08100 Nuoro, Italy; mariafrap@tiscali.it (M.F.P.); \\ mgatzori.mga@gmail.com (M.G.A.) \\ 2 Dermatology Clinic, Department Medical Sciences and Public Health, Cagliari State University, \\ 09124 Cagliari, Italy; ferreli@unica.it \\ * Correspondence: atzoril@unica.it; Tel.: +39-3388-526-881; Fax: +39-0705-109-2103
}

Citation: Peigottu, M.F.; Ferreli, C.; Atzori, M.G.; Atzori, L. Skin Adverse Reactions to Novel Messenger RNA Coronavirus Vaccination: A Case Series. Diseases 2021, 9, 58. https:// doi.org/10.3390/diseases 9030058

Academic Editor: Maurizio Battino

Received: 4 July 2021

Accepted: 25 August 2021

Published: 27 August 2021

Publisher's Note: MDPI stays neutral with regard to jurisdictional claims in published maps and institutional affiliations.

Copyright: (c) 2021 by the authors. Licensee MDPI, Basel, Switzerland. This article is an open access article distributed under the terms and conditions of the Creative Commons Attribution (CC BY) license (https:// creativecommons.org/licenses/by/ $4.0 /)$.

\begin{abstract}
Vaccines are actually the most effective strategy to control the COVID-19 spread and reduce mortality, but adverse reactions can occur. Skin involvement with novel messenger RNA coronavirus vaccines seems frequent but is not completely characterized. A real-world experience in the recent vaccination campaign among health care workers in Sardinia (Italy) is reported. In over a total of 1577 persons vaccinated, 9 cases of skin adverse reactions were observed $(0.5 \%)$. All reactions have been reported to the Italian Pharmacovigilance Authority. Eight occurred in women (mean age 46 years), and five were physicians and four nurses. All patients had a significant allergology history but not for the known vaccine excipients. After dose one, no injection site reactions were observed, but widespread pruritus $(n=3)$, mild facial erythema $(n=1)$, and maculopapular rash $(n=3)$ occurred in the following $24-48 \mathrm{~h}$ in three patients. These three patients were excluded from the second dose. Of the remaining six patients, one developed mild anaphylaxis within the observation period at the vaccination hub and five delayed facial erythematous edema and maculopapular lesions, requiring antihistamines and short-course corticosteroid treatment. Spontaneous reporting is paramount to adjourning vaccination guidance and preventive measures in order to contribute to the development of a safe vaccine strategy. Dermatologist' expertise might provide better characterization, treatment, and screening of individuals at high risk of skin adverse reactions.
\end{abstract}

Keywords: skin adverse reactions; novel messenger RNA coronavirus vaccine; COVID-19 vaccination; delayed skin reactions

\section{Introduction}

The novel messenger RNA (mRNA) technology vaccines are a crucial part of the worldwide fight against coronavirus disease 2019 (COVID-19), and the Pfizer-BioNTech vaccine has been the first issued in Italy for the health care workers' vaccination program. Reported adverse effects in clinical trials include minimal local skin reactions, especially following the required second dose of the vaccine, without systemic adverse reactions [1,2]. However, individuals with a history of a severe adverse reaction related to the vaccine and/or other severe allergic reactions (e.g., anaphylaxis) were excluded from pivotal approval studies, and in a registry-based study of 414 cases, a spectrum of cutaneous reactions after mRNA COVID-19 Moderna (83\%) and Pfizer (17\%) vaccines was reported [3]. Fortythree percent of patients with first-dose reactions experienced second-dose recurrence. No serious adverse events developed in any of the patients, thus not discouraging vaccination.

However, the Centers for Disease Control and Prevention (CDC) recommends to avoid a second dose if a severe or immediate allergic reaction to the first dose of an mRNA COVID-19 vaccine has occurred [4]. Assessment with excipient skin testing in 80 patients reporting an allergic reaction to $\mathrm{mRNA}$ COVID-19 vaccine dose one, a sensitization to PEG $(n=5)$ and/or polysorbate $80(n=12)$ was documented in a minority of patients, and most of the patients received the second dose safely [5]. 
The present short case series documents the real-world experience in the recent vaccination campaign among health care workers in Sardinia, a major island in the Mediterranean basin, and all reactions have been reported to the Italian Pharmacovigilance Authority.

\section{Case Series}

Of over a total of 1577 persons vaccinated during the first vaccination round, which ended in January 2021, 9 cases of skin adverse reactions were observed (0.5\%). As regards demographics (Table 1), eight occurred in women, the age ranged from 35 to 55 years (mean 46 years), five were physicians, and four were nurses.

Table 1. Patients' data and experienced cutaneous adverse reactions to Pfizer-BioNTech vaccination.

\begin{tabular}{|c|c|c|c|c|c|}
\hline $\begin{array}{c}\text { Patient Sex } \\
\text { and Age }\end{array}$ & Work & $\begin{array}{l}\text { Allergology } \\
\text { Anamnesis }\end{array}$ & 1st Dose & 2nd Dose & Treatment \\
\hline Woman, 40 years & Physician & $\begin{array}{l}\text { Atopy, anaphylaxis } \\
\text { to penicillin and } \\
\text { cephalosporin }\end{array}$ & No reaction & $\begin{array}{l}\text { Face erythema and } \\
\text { swelling } 20 \text { min after } \\
\text { injection }\end{array}$ & $\begin{array}{l}\text { Spontaneous } \\
\text { remission in } 30 \mathrm{~min}\end{array}$ \\
\hline Woman, 52 years & Nurse & $\begin{array}{l}\text { Penicillin allergy, } \\
\text { nickel allergy }\end{array}$ & $\begin{array}{l}\text { Widespread } \\
\text { itch }\end{array}$ & $\begin{array}{c}\text { Urticarial rash } \\
30 \text { min after injection }\end{array}$ & $\begin{array}{c}\text { Antihistamine }+ \\
\text { short-course steroids }\end{array}$ \\
\hline Woman, 55 years & Nurse & $\begin{array}{c}\text { Atopy, } \\
\text { cephalosporin } \\
\text { allergy, lactose } \\
\text { intolerance }\end{array}$ & $\begin{array}{l}\text { Widespread itch and } \\
\text { facial erythema } 8 \mathrm{~h} \\
\text { after injection }\end{array}$ & $\begin{array}{l}\text { Erythematous } \\
\text { maculopapular } \\
\text { eruption } 24 \mathrm{~h} \text { after } \\
\text { injection }\end{array}$ & $\begin{array}{c}\text { Antihistamine + } \\
\text { short-course steroids }\end{array}$ \\
\hline Woman, 35 years & Physician & Atopy & $\begin{array}{l}\text { Glottis edema and } \\
\text { facial erythema } 20 \\
\text { min after injection }\end{array}$ & Not performed & $\begin{array}{c}\text { Antihistamine + } \\
\text { short-course steroids }\end{array}$ \\
\hline Woman, 51 years & Nurse & Atopy, anaphylaxis & $\begin{array}{l}\text { Urticarial rash with } \\
\text { arthralgias in the } 24 \mathrm{~h} \\
\text { after injection }\end{array}$ & Not performed & Short-course steroids \\
\hline Woman, 62 years & Physician & $\begin{array}{c}\text { Previous } \\
\text { angioedema (no } \\
\text { identified cause) }\end{array}$ & $\begin{array}{c}\text { Widespread } \\
\text { maculopapular } \\
\text { eruption } 24 \mathrm{~h} \text { after } \\
\text { injection }\end{array}$ & Not performed & Antihistamine \\
\hline Woman, 37 years & Nurse & Penicillin allergy & $\begin{array}{l}\text { Persistent itch, } \\
\text { especially on the } \\
\text { scalp }\end{array}$ & $\begin{array}{l}\text { Erythematous } \\
\text { maculopapular } \\
\text { eruption } 48 \mathrm{~h} \text { after } \\
\text { injection }\end{array}$ & $\begin{array}{c}\text { Antihistamine + } \\
\text { short-course steroids }\end{array}$ \\
\hline Woman, 41 years & Physician & $\begin{array}{l}\text { Atopy, drug } \\
\text { allergy }\end{array}$ & Widespread itch & $\begin{array}{l}\text { Erythematous } \\
\text { maculopapular } \\
\text { eruption } 48 \mathrm{~h} \text { after } \\
\text { injection }\end{array}$ & Antihistamine \\
\hline Man, 41 years & Physician & $\begin{array}{l}\text { Atopy, drug } \\
\text { allergy }\end{array}$ & No reaction & $\begin{array}{l}\text { Erythematous } \\
\text { maculopapular } \\
\text { eruption } 48 \mathrm{~h} \text { after } \\
\text { injection }\end{array}$ & Antihistamine \\
\hline
\end{tabular}

All patients had a significant allergology history: atopy in five, penicillin allergy in four, additional drug allergy in three, and contact dermatitis in three patients. However, none of the patients had a documented allergy to substances regarded as potentially predisposing to mRNA vaccines, such as latex, polyethylene glycol, polyoxyl castor oil, or polysorbate. Angioedema and anaphylaxis were reported in three patients. It is noteworthy that the Italian guidelines on the allergology screening for patients with a history of asthma and allergy were released quite after the first dose of the vaccine had been performed [6], and the decision whether to administrate dose two had to be individualized. Priority to the broad vaccination coverage of the health care community was recognized in the 
midst of the pandemic. It should be considered that Nuoro has been the second city in Sardinia for the number of COVID-19 cases, with a high percentage of health care workers severely affected.

As regards presentation of skin adverse events, and timing, no injection site reactions were observed. After the first dose, two patients did not manifest any reaction, three patients noted late-onset widespread pruritus, and one showed mild transitory facial erythema, not requiring intervention. In the remaining three patients, a maculopapular rash developed $48 \mathrm{~h}$ after injection. Allergology consulting excluded administration of the second dose in the latter three patients, while the risk for the other six patients was considered low and the vaccination was completed. One patient experienced glottis edema, within the observation timing at the vaccination hub, receiving epinephrine, but with fast and complete recovery. The other five patients, $24-48 \mathrm{~h}$ after injection, developed facial erythematous edema and widespread itching maculo-papular lesions (Figure 1), Mild general malaise, with muscle weakness and migrating arthralgias but not fever, was also reported. Treatment consisted of oral antihistamines and a short course of systemic steroids.

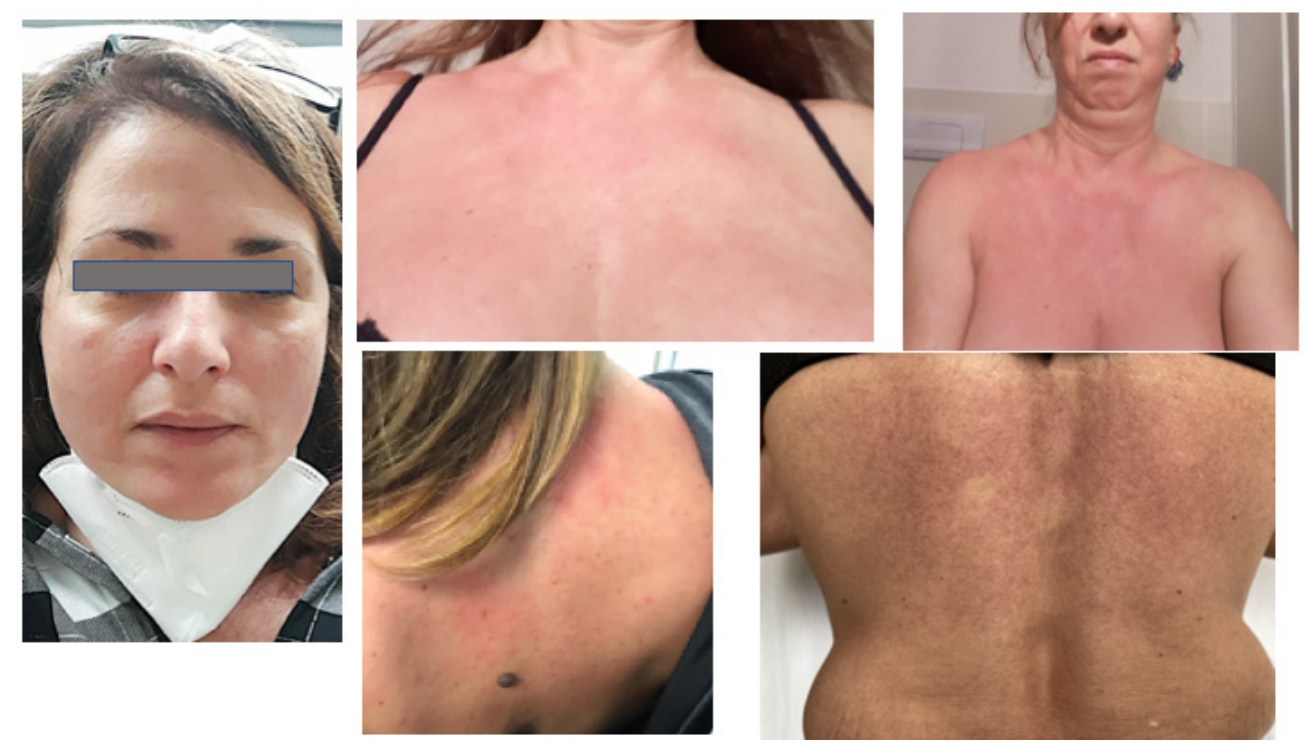

Figure 1. Erythematous edematous and maculopapular eruptions in 4 different patients after Pfizer/BioNTech vaccination.

\section{Discussion}

As dermatologists, we are actively committed to supporting the Vaccine Adverse Event Reporting System (VAERS) and enhancing continuous safety monitoring [7]. Severe allergic reactions to vaccines are rare but can be life threatening. The BNT162b2 vaccine is based on lipid nanoparticles and other substances to enable transport of messenger RNA (mRNA) molecules into the cells, which can be potential allergens. In Pfizer-BioNTech COVID-19 vaccine approval clinical trials, injection site pain was frequently reported ( $84.1 \%$ of recipients), followed by swelling (10.5\%) and erythema (9.5\%) [2]. The McMahon et al. registry documented delayed large local reactions, followed by local injection site reactions and several manifestations that mimicked SARS-CoV-2 infection itself, such as pernio/chilblains, urticarial eruptions, and morbilliform eruptions [3]. Less commonly described reactions included cosmetic filler reactions, zoster, herpes simplex flares, and pityriasis rosea-like reactions. Unfortunately, the study did not report the number of vaccinated individuals among which the 414 patients developed the skin manifestations. Nor did it allow a real evaluation of the differences between the two vaccines, as the relative safety of Pfizer in respect to Moderna reactions might depend on a less extensive use of the Pfizer vaccine in the United States. 
Our experience confirms that Pfizer-BioNTech vaccine skin reactions are uncommon $(0.5 \%)$ but suggests implementing allergology screening and prophylaxis measures, not to undervalue delayed skin reactions. Clinical trials and post-marketing experience focus on anaphylactic reactions that occurred within a $30 \mathrm{~min}$ observation window, and patients were treated immediately with complete resolution of symptoms [2,8]. However, only one of our patients developed anaphylaxis while on the vaccination hub. All other patients had delayed reactions. The health care workers involved in this Italian vaccination program were carefully informed and had specific knowledge of adverse reaction occurrence, allowing prompt recognition and treatment, including self-medication, which might be not the case with the general population, alone at home after the vaccination procedure.

Alerting signs after dose one (Table 2) that should be considered are a generalized itching and even slight facial erythematous edema, requiring allergology consulting. A careful allergology personal history appears the most important moment, which should not be limited to the evaluation of known vaccine excipient sensitization. Skin testing before vaccine dose two administration was not predictive in a recent study, with negative skin tests in patients who developed reactions to their 388 mRNA COVID-19 vaccine second dose [5].

Table 2. Post-vaccinated dose one reactions and second dose risk assessment.

\begin{tabular}{|c|c|c|}
\hline Clinical Phenotyping & Second Dose Risk & Advertisements \\
\hline $\begin{array}{l}\text { No reactions at first dose, but } \\
\text { history of atopy, penicillin, or other } \\
\text { drug allergy, contact dermatitis }\end{array}$ & Low risk & $\begin{array}{l}\text { Second dose: instruct the } \\
\text { patient about delayed reaction } \\
(>4 \mathrm{~h}) \text { reporting }\end{array}$ \\
\hline \multicolumn{3}{|c|}{ Immediate skin reactions $(<4 \mathrm{~h})$ but not anaphylaxis } \\
\hline Only subjective symptoms & Low risk & $\begin{array}{l}\text { Second dose: instruct the } \\
\text { patient about delayed reaction } \\
(>4 \mathrm{~h}) \text { reporting }\end{array}$ \\
\hline $\begin{array}{l}\text { Widespread itch } \\
\text { Facial erythema }\end{array}$ & Medium risk & $\begin{array}{l}\text { Second dose with prolonged } \\
\text { post-vaccination observation: } \\
\text { support for delayed reactions }\end{array}$ \\
\hline Labial-glottis edema & High risk & $\begin{array}{l}\text { Allergology evaluation and } \\
\text { skin testing for vaccine } \\
\text { excipients (i.e., PEG 3350) } \\
\text { Decision sharing with } \\
\text { supervision physician on } \\
\text { second dose vaccination }\end{array}$ \\
\hline \multicolumn{3}{|l|}{ Delayed skin reactions $(>4 \mathrm{~h})$} \\
\hline $\begin{array}{l}\text { Widespread itch, general malaise, } \\
\text { arthralgias } \\
\text { Facial erythema } \\
\text { Large local reaction } \\
\text { Urticarial rash } \\
\text { Maculopapular rash }\end{array}$ & Medium-to-high risk & $\begin{array}{l}\text { Allergology evaluation and } \\
\text { skin testing for vaccine } \\
\text { excipients (i.e., PEG 3350) } \\
\text { Decision sharing with } \\
\text { supervision physician on } \\
\text { second dose vaccination }\end{array}$ \\
\hline
\end{tabular}

In our experience, the personal allergy history was positive for penicillin and other drug reactions, instead of the allergens considered related to the messenger RNA (mRNA) vaccine, such as polyethylene glycol, polyoxyl castor oil, or polysorbate.

Another uncovered issue is the opportunity of a premedication regimen, such as with non-sedating antihistamines for patients with mild symptoms at dose one $[3,4,7]$. Major health care agencies, including the $\mathrm{CDC}$, discourage preventive administration of antihistamines, because there is no current evidence that they cannot interfere with vaccine effectiveness. However, in a recent experimental setting, it was demonstrated that histamine $\mathrm{H} 1$ antagonists, especially desloratadine, could bind angiotensin-converting enzyme 2 (ACE2), blocking interactions with the viral spike (S) glycoprotein, thus prevent- 
ing the virus's entrance into cells [9]. Antihistamines seems to work like antibodies. The COVID-19 molecules of mRNA enter the membrane via an endocytosis mechanism and are released into the cytoplasm of the muscle cells, independently from angiotensin-converting enzyme 2 (ACE2). Once inside the cell, mRNA gets translated by a ribosome and induces the release of SARS-CoV-2 spike protein, which can be detected by immune cells in the tissue and induce antibody production. Thus, antihistamines should not interfere with mRNA vaccine entrance and functions. If confirmed, antihistamines are candidates as an effective therapeutic option for COVID-19, and might be considered a safe preventive measure against vaccine reactions in allergic individuals.

The low rate of reactions and favorable course in all the nine patients might be helpful to reassure patients as well as health care providers that the vaccination program is safe and affordable even in allergic patients.

\section{Conclusions}

Careful surveillance over time and spontaneous reporting of mRNA-based COVID-19 vaccine safety are crucial measures to better characterize morphology and timing, as well as predisposing conditions. Dermatologists' expertise in proper diagnosis will contribute to the definition of the spectrum of skin adverse reactions and provide insights into the possible mechanisms, as well as suggest appropriate screening for high-risk individuals. Our case series does not reach a statistical power, and large epidemiological studies will be hopefully provided by nation-wide registers. No premedication was supplied to the patients, following the Italian recommendation for SARS-CoV-2 at the vaccination hub. So, only the vaccine composition should be associated with the reactions. As regards skin testing, patients with more severe reactions were evaluated by the allergologists and were negative for vaccine excipients and cross-reactive substance sensitization. The fact that the skin reaction in some patients was triggered only by the second dose is a common finding with drugs adverse reactions and was confirmed in recent 388 mRNA COVID-19 vaccine studies. It is for this reason that intradermal testing for a local anesthetic is no more routinely performed, as in several cases, the reaction was negative at testing, while the local injection during following surgery or a dentistry procedure triggered true anaphylaxis.

As the world fights COVID-19, the medical community is gaining more experience in the risk-benefit assessment before vaccination, and guidance should be regularly updated. Avoidance of any hazard is necessary to reassure patients of the need to accept this important preventative measure.

Author Contributions: Conceptualization, L.A. and M.G.A.; methodology, L.A. and M.G.A.; data curation M.F.P. and C.F.; writing — original draft preparation, M.F.P.; writing—review and editing, L.A.; visualization, M.F.P. and C.F.; supervision, L.A. All authors have read and agreed to the published version of the manuscript.

Funding: This research received no external funding.

Institutional Review Board Statement: The study was conducted according to the guidelines of the Declaration of Helsinki. Approval by the Local Ethics Committee is not applicable, because active pharmacovigilance studies on vaccine safety are obligatory in Italy. As stated in the manuscript, all reactions add been reported to the National Pharmacovigilance Agency.

Informed Consent Statement: Informed consent was obtained from all subjects involved in the study.

Data Availability Statement: The data presented in this study are available on request from the corresponding author.

Acknowledgments: We would like to thank all health care workers of the San Francesco Hospital, Nuoro (Italy) for engagement in adverse skin event reporting.

Conflicts of Interest: The authors declare no conflict of interest. 
Authorship Statement: The authors certify that the manuscript is original and has never been submitted to other journals for publication before. All authors contributed equally to the manuscript and had the opportunity to revise and approve the final text.

\section{References}

1. CDC. COVID-19 Cases, Deaths, and Trends in the US I CDC COVID Data Tracker. Available online: https:/ / covid.cdc.gov/coviddata-tracker (accessed on 21 December 2020).

2. FDA. Pfizer-BioNTech COVID-19 Vaccine. Available online: https://www.fda.gov/emergency-preparedness-and-response/ coronavirus-disease-2019-covid-19/pfizer-biontechcovid-19-vaccine (accessed on 21 December 2020).

3. McMahon, D.E.; Amerson, E.; Rosenbach, M.; Lipoff, J.B.; Moustafa, D.; Tyagi, A.; Desai, S.R.; French, L.E.; Lim, H.W.; Thiers, B.H.; et al. Cutaneous reactions reported after Moderna and Pfizer COVID-19 vaccination: A registry-based study of 414 cases. J. Am. Acad. Dermatol. 2021, 85, 46-55. [CrossRef] [PubMed]

4. COVID-19 Vaccines for People with Allergies. Available online: https://www.cdc.gov (accessed on 25 March 2021).

5. Wolfson, A.R.; Robinson, L.B.; Li, L.; Cogan, A.S.; Fu, X.; Wickner, P.; Samarakoon, U.; Saff, R.R.; Blumenthal, K.G.; Banerji, A. First Dose mRNA COVID-19 Vaccine Allergic Reactions: Limited Role for Excipient Skin Testing. J. Allergy Clin. Immunol. Pract. 2021. [CrossRef] [PubMed]

6. Associazione Allergologi, Immunologi Italiani Territoriali e Ospedalieri; Società Italiana di Allergologia, Asma ed Immunologia Clinica. Linee di Indirizzo per la Gestione da Parte Degli Allergologi dei Pazienti a Rischio di Reazioni Allergiche ai Vaccini per Covid-19. Available online: http:/ / www.siaaic.org/?p=5569 (accessed on 15 January 2021).

7. Pulsipher, K.J.; Presley, C.L.; Waller, J.D.; Szeto, M.D.; Laughter, M.R.; Dellavalle, R.P. Coronavirus Vaccination Adverse Reactions and the Role of the Dermatologist. J. Drugs Dermatol. 2021, 20, 351-352. [CrossRef] [PubMed]

8. Banerji, A.; Wickner, P.G.; Saff, R.; Stone, C.A., Jr.; Robinson, L.B.; Long, A.A.; Wolfson, A.R.; Williams, P.; Khan, D.A.; Phillips, E.; et al. mRNA Vaccines to Prevent COVID-19 Disease and Reported Allergic Reactions: Current Evidence and Suggested Approach. J. Allergy Clin. Immunol. Pract. 2021, 9, 1423-1437. [CrossRef] [PubMed]

9. Hou, Y.; Ge, S.; Li, X.; Wang, C.; He, H.; He, L. Testing of the inhibitory effects of loratadine and desloratadine on SARS-CoV-2 spike pseudotyped virus viropexis. Chem.-Biol. Interact. 2021, 338, 109420. [CrossRef] [PubMed] 